\title{
Reducing Grain Sorghum (Sorghum bicolor L. Moench) Injury From Postemergence Application of Mesotrione With Dicamba
}

\author{
Taghi Bararpour ${ }^{1}$, Gurbir Singh ${ }^{1}$, Ralph R. Hale ${ }^{1} \&$ Gurpreet Kaur $^{1}$ \\ ${ }^{1}$ Delta Research and Extension Center, Mississippi State University, Stoneville, Mississippi, USA \\ Correspondence: Gurpreet Kaur, Delta Research and Extension Center, Mississippi State University, 82 \\ Stoneville Rd., Stoneville, Mississippi 38776, USA. Tel: 1-662-686-9311. E-mail: gk340@msstate.edu
}

Received: September 2, 2020

Accepted: October 22, $2020 \quad$ Online Published: November 15, 2020

doi:10.5539/jas.v12n12p1

URL: https://doi.org/10.5539/jas.v12n12p1

\begin{abstract}
Weed management in grain sorghum is limited by the number of herbicide options. A two-year (2017-2018) field study was conducted at the Mississippi State University Delta Research and Extension Center, in Stoneville, MS to evaluate the response of grain sorghum to mesotrione application alone or when tank-mixed with dicamba at the two-leaf and four-leaf growth stage of sorghum. Mesotrione was applied at 0.07 and $0.105 \mathrm{~kg}^{-1 i} \mathrm{ar}^{-1}$ alone or was tank-mixed with dicamba at $0.28 \mathrm{~kg}_{\text {ae ha }}{ }^{-1}$. Significant injury to grain sorghum from all herbicide treatments was observed compared with the untreated check. Increase in mesotrione application rate increased injury to grain sorghum from 14 to $19 \%$ at two-leaf and from 10 to $24 \%$ at the four-leaf stage by 4 weeks after application (WAA) in 2017. Adding dicamba to mesotrione reduced grain sorghum injury in both years. At 4-leaf sorghum application stage, mesotrione applied at $0.07 \mathrm{~kg} \mathrm{ha}^{-1}$ resulted in greater grain yield than all other herbicide treatments, except mesotrione $\left(0.105 \mathrm{~kg} \mathrm{ha}^{-1}\right)+$ NIS in 2017 . Our results indicate that adding dicamba to mesotrione safes grain sorghum from injury caused by mesotrione alone.
\end{abstract}

Keywords: callisto, clarity, plant height, heading, yield

\section{Introduction}

Grain sorghum (Sorghum bicolor L. Moench) is an important cereal crop grown in the United States. In 2019, U.S. harvested 4.6 million ha of grain sorghum (USDA-NASS, 2020). Cultural practices, like crop rotation, are important for weed control in grain sorghum along with incorporating herbicide programs (Brown, Al-Khatib, Regehr, Stahlman, \& Loughin, 2004). Unlike corn (Zea mays L.), cotton (Gossypium hirsutum L.), or soybean (Glycine $\max$ L. Merr.), there are limited options for weed control in grain sorghum.

Amaranthus spp. are among the most troublesome weeds in grain sorghum. In a competition study, Knezevic, Horak, and Vanderlip (1997) reported a 47\% yield reduction to grain sorghum when redroot pigweed (Amaranthus retroflexus L.) emerged once grain sorghum had reached the 2.6-leaf stage. In a different study, grain sorghum yield was reduced by $48 \%$ when one Amaranthus plant per $30 \mathrm{~cm}^{2}$ was present (Shipley \& Wiese, 1969). In addition, Palmer amaranth (Amranthus palmeri S.Wats.) present in grain sorghum fields caused increased moisture in grain and other foreign materials at the time of harvest (Moore, Murray, \& Westerman, 2004). Since chemical control of troublesome weeds are important in grain sorghum production, there is a need for new herbicide options for control (Abit et al., 2009).

Preemergence weed control in sorghum can be achieved by using atrazine, S-metolachlor, dimethenamid-p, or alachlor and postemergence with 2,4-D, dicamba, or bromoxynil (Smith \& Scott, 2010). Mesotrione is labeled to use in corn to control annual broadleaf and some grass weeds in corn (Janak \& Grichar, 2016; Mitchell et al., 2001), including triazine-resistant Palmer amaranth, common waterhemp (Amranthus rudis Sauer), common lambsquarters (Chenopodium album L.), and black nightshade (Solanum nigrum L.), and ALS resistant weeds including Amaranthus ssp., common cocklebur (Xanthium strumarium L.), and annual sowthistle (Sonchus oleraceus L.) (Abit et al., 2009; Sutton, Richards, Buren, \& Glasgow, 2002). Mesotrione is labeled to use as preplant and preemergence for weed control in grain sorghum (Abit et al., 2009). However, its postemergence applications have been reported to cause injury to sorghum plants. Mesotrione applied at $70.5 \mathrm{~g}$ ai ha ${ }^{-1}$ resulted in $20 \%$ chlorosis injury in grain sorghum but provided consistent weed control (Horky \& Martin, 2004). In another study, Miller and Regehr (2002) reported early postemergence applications of mesotrione to grain sorghum exhibited $40-60 \%$ bleaching, but late postemergence applications exhibited less grain sorghum injury. Therefore, it 
is possible that mixing mesotrione with other herbicides will alleviate the injury caused on sorghum plants by mesotrione.

Limited research has indicated that the use of some growth regulators, like 2,4-D or dicamba, may save some herbicides in causing injury. Brown et al. (2004) reported 2,4-D and dicamba in combination with metsulfuron or fluroxypyr exhibited less injury to grain sorghum compared to metsulfuron applied alone. Bararpour, Norsworthy, Hale, and Jones (2017) reported the lowest grain sorghum injury (23\%) when mesotrione was applied with dicamba postemergence compared to the combination of mesotrione and atrazine (54\%) at $2 \mathrm{wk}$ after application (WAA); furthermore, grain sorghum recovered by 4 WAA with only $2 \%$ injury with mesotrione and dicamba and $7 \%$ injury with mesotrione and atrazine. A reduction in the injury level observed with mesotrione when added to dicamba may indicate that the addition of dicamba will safen mesotrione, but more research is needed to validate it for sorghum planted in Mid-South United States. Therefore, the objective of this research was to validate the claim that the addition of dicamba to applications of mesotrione will safen grain sorghum against injury when applied postemergence.

\section{Materials and Methods}

Field studies were conducted in 2017 and 2018 at the Mississippi State University Delta Research and Extension Center in Stoneville, MS. Experiments were conducted on Sharkey clay (very-fine, smectitic, thermic Chromic Epiaquerts) with $2.4 \%$ organic matter and $\mathrm{pH}$ 7.5. A hybrid grain sorghum variety Pioneer ' $84 \mathrm{P} 80$ ' (Corteva Agriscience, Indianapolis, IN) was planted on June 8 and May 31 in 2017 and 2018, respectively, at a seeding rate of 23 seeds $\mathrm{m}^{-1}$ row length. This variety was selected for its high yielding characteristic and is commonly grown around the U.S. The plot size was $4 \mathrm{~m}$ wide by $6 \mathrm{~m}$ long. Row spacing was $102 \mathrm{~cm}$ and there were four rows of sorghum in each plot.

The experimental design was a randomized complete block with a factorial arrangement of treatments. Experiments contained two factors including the two-application timings of herbicides (2-leaf stage, 4-leaf stage) and nine herbicide treatments (Table 1). The trade names, site of action, chemical group, and manufacturer information for herbicides used in this study are listed in Table 2. Mesotrione was applied at two rates at 0.07 and $0.105 \mathrm{~kg}_{\text {ai ha }}{ }^{-1}$ at 2- and 4-leaf stage of grain sorghum either alone or tank-mix with dicamba at $0.28 \mathrm{~kg}$ ae ha ${ }^{-1}$. Herbicide treatments were applied on June 26, 2017 and June 28, 2018 for the 2-leaf stage of grain sorghum. For 4-leaf stage application timing, the herbicides were applied on July 7, 2017 and July 10, 2018. Environmental data at each application timing in 2017 and 2018 are listed in Table 3. A non-treated control was also included in the study. Herbicide applications were made using a $\mathrm{CO}_{2}$-pressurized backpack sprayer calibrated to deliver $141 \mathrm{~L} \mathrm{ha}^{-1}$ at $276 \mathrm{kPa}$. The boom consisted of 51-cm nozzle spacing equipped with Turbo TeeJet (TeeJet Technologies, Springfield, IL) Induction (TTI) 110015 nozzles.

Table 1. Herbicide treatments and their application rate used in this study

\begin{tabular}{|c|c|c|c|}
\hline Treatment & Herbicide & Application rate & Application timing \\
\hline & & $\mathrm{kg}$ ai ha ${ }^{-1}$ & \\
\hline M1 & Mesotrione & 0.07 & 2lf, $41 f^{\S}$ \\
\hline M2 & Mesotrione & 0.105 & 2lf, 4lf \\
\hline $\mathrm{M} 1+\mathrm{NIS}^{\dagger}$ & Mesotrione + Induce (NIS) & 0.07 & 2lf, 4lf \\
\hline $\mathrm{M} 2+\mathrm{NIS}$ & Mesotrione + Induce (NIS) & 0.105 & 2lf, 4lf \\
\hline $\mathrm{M} 1+\mathrm{C}$ & Mesotrione + Dicamba & $0.07+0.28^{\ddagger}$ & 2lf, 4lf \\
\hline $\mathrm{M} 2+\mathrm{C}$ & Mesotrione + Dicamba & $0.105+0.28$ & 2lf, 4lf \\
\hline $\mathrm{M} 1+\mathrm{C}+\mathrm{NIS}$ & Mesotrione + Dicamba + Induce (NIS) & $0.07+0.28$ & 2lf, 4lf \\
\hline $\mathrm{M} 2+\mathrm{C}+\mathrm{NIS}$ & Mesotrione + Dicamba + Induce (NIS) & $0.105+0.28$ & 2lf, 4lf \\
\hline NTC & Nontreated Check & - & - \\
\hline
\end{tabular}

Note. $\dagger$ NIS $=$ Non-ionic surfactant at $0.25 \% \mathrm{v} / \mathrm{v} . \dagger$ Clarity is in $\mathrm{kg}$ ae ha ${ }^{-1} . \S \mathrm{lf}=$ leaf. 
Table 2. Herbicide treatments including their trade name, manufacturer, chemical family, group, and site of action used in the study

\begin{tabular}{llllll}
\hline $\begin{array}{l}\text { Herbicide Treatments } \\
\text { (common name) }\end{array}$ & Trade Name & Manufacturer & Chemical family & Group & Site of action \\
\hline Mesotrione & Callisto (4L) & $\begin{array}{l}\text { Syngenta Crop Protection, LLC, } \\
\text { Greensboro, NC 27,419 }\end{array}$ & Triketone & 27 & $\begin{array}{l}\text { 4-hydroxyphenyl-pyruvatedioxygenase } \\
\text { (4-HPPD) inhibitor }\end{array}$ \\
Dicamba & Clarity (4SL) & $\begin{array}{l}\text { BASF Corporation, Research } \\
\text { Triangle Park, NC 27,709 }\end{array}$ & Benzoic acid & 4 & Synthetic Auxin \\
\hline
\end{tabular}

Table 3. Environmental data at the time of each application (2-leaf and 4-leaf stages of grain sorghum) in 2017 and 2018

\begin{tabular}{|c|c|c|c|c|}
\hline & \multicolumn{4}{|c|}{ Herbicide application timing } \\
\hline & \multicolumn{2}{|c|}{ 2-leaf stage } & \multicolumn{2}{|c|}{ 4-leaf stage } \\
\hline & 2017 & 2018 & 2017 & 2018 \\
\hline Application date & 26 June & 28 June & 7 July & 10 July \\
\hline Air temperature $\left({ }^{\circ} \mathrm{C}\right)$ & 31 & 28 & 27 & 27 \\
\hline$\%$ Relative humidity & 69 & 78 & 78 & 77 \\
\hline Wind velocity $\left(\mathrm{km} \mathrm{hr}^{-1}\right)$ & 4.8 & 4.0 & 6.4 & 3.2 \\
\hline Soil temperature $\left({ }^{\circ} \mathrm{C}\right)$ & 29 & 28 & 28 & 26 \\
\hline
\end{tabular}

Visual injury assessments consisted of estimating treated plants that exhibited symptomologies such as bleaching (which is general symptomology of mesotrione application), stunting, necrosis, and/or chlorosis. Ratings were based on a scale of 0 to $100 \%$, with $0 \%$ being no injury and $100 \%$ being complete crop death, relative to the nontreated check. Injury ratings were taken thrice after herbicide application and dates for injury rating assessment is provided in Tables 4 and 5. Data on plant height and percent heading in sorghum was also collected afer final injury assessment. Grain sorghum was harvested using a Kincaid plot combine on October 17, 2017. Plots were not harvested in 2018 for yield due to untimely rain and high-intensity winds during harvesting season which led to grain loss.

All the collected data were analyzed using SAS statistical software (SAS Institute Inc., Cary, NC) using the GLIMMIX procedure. Prior to analysis, all data was analyzed for normality using the UNIVARIATE procedure in SAS. All of the data was normally distributed. The herbicide treatments and application timing were considered fixed effects, whereas treatment replication was considered as random. Data were analyzed separately for each year since there was a significant effect of the year. Means were separated using T-grouping $(\alpha=0.05)$.

\section{Results and Discussion}

\subsection{Year 2017}

In 2017, the injury to grain sorghum assessed on 1 August and 17 August was affected by the interaction of application timing and herbicide treatments as well as by the main effects of application timing and herbicide treatments (Table 4). First grain sorghum physical injury was evaluated four weeks after application (WAA). Averaged over herbicide treatments, grain sorghum showed greater injury to mesotrione application at 4-leaf growth stage $(15 \%)$ than at 2-leaf growth stage $(10 \%)$ (Figure $1 \mathrm{~A})$. This result may again indicate that grain sorghum is less sensitive to mesotrione application at 2-leaf than 4-leaf. Grain sorghum injury increased from $14 \%$ to $19 \%$ as mesotrione (alone) application rate at 2-leaf growth stage increased from $0.07 \mathrm{~kg} \mathrm{ha}^{-1}$ to $0.105 \mathrm{~kg}$ $\mathrm{ha}^{-1}$ (Figure 1A). Similarly, increasing mesotrione (alone) application rate from $0.07 \mathrm{~kg} \mathrm{ha}^{-1}$ to $0.105 \mathrm{~kg} \mathrm{ha}^{-1}$ at $4-$ leaf growth stage increased injury to sorghum plants from $10 \%$ to $24 \%$. Grain sorghum injury level was 16 and $15 \%$ from 0.07 and $0.105 \mathrm{~kg} \mathrm{ha}^{-1}$ mesotrione alone + NIS applications at 2-leaf growth stage, respectively. However, the application of dicamba with mesotrione to the tank at 2-leaf growth stage reduced grain sorghum injury 4 WAA (Figure 1A). This indicates that dicamba had safening effect on grain sorghum from mesotrione. 
Table 4. Probability values for year 2017 data generated from statistical model associated with injury ratings, plant height, sorghum heading and sorghum grain yield determined for herbicide treatments and application timing

\begin{tabular}{|c|c|c|c|c|c|c|c|}
\hline \multirow{2}{*}{ Source of variation } & \multirow{2}{*}{ df } & \multicolumn{3}{|c|}{ Injury rating (2017) } & \multirow{2}{*}{ Plant height (cm) } & \multirow{2}{*}{ Heading (\%) } & \multirow{2}{*}{ Grain yield $\left(\mathrm{kg} \mathrm{ha}^{-1}\right)$} \\
\hline & & 1 August & 17 August & 29 August & & & \\
\hline Herbicide Treatment (HT) & 8 & $\begin{array}{l}<0.0001 \\
------\end{array}$ & 0.0017 & 0.0867 & $\begin{array}{l}<\mathbf{0 . 0 0 0 1} \\
\end{array}$ & 0.0051 & 0.0582 \\
\hline Application Timing (AT) & 1 & $<0.0001$ & 0.0314 & 0.1245 & 0.5078 & 0.1657 & 0.0037 \\
\hline $\mathrm{HT} \times \mathrm{AT}$ & 8 & $<0.0001$ & 0.0367 & 0.8595 & 0.2328 & 0.9953 & 0.0003 \\
\hline
\end{tabular}
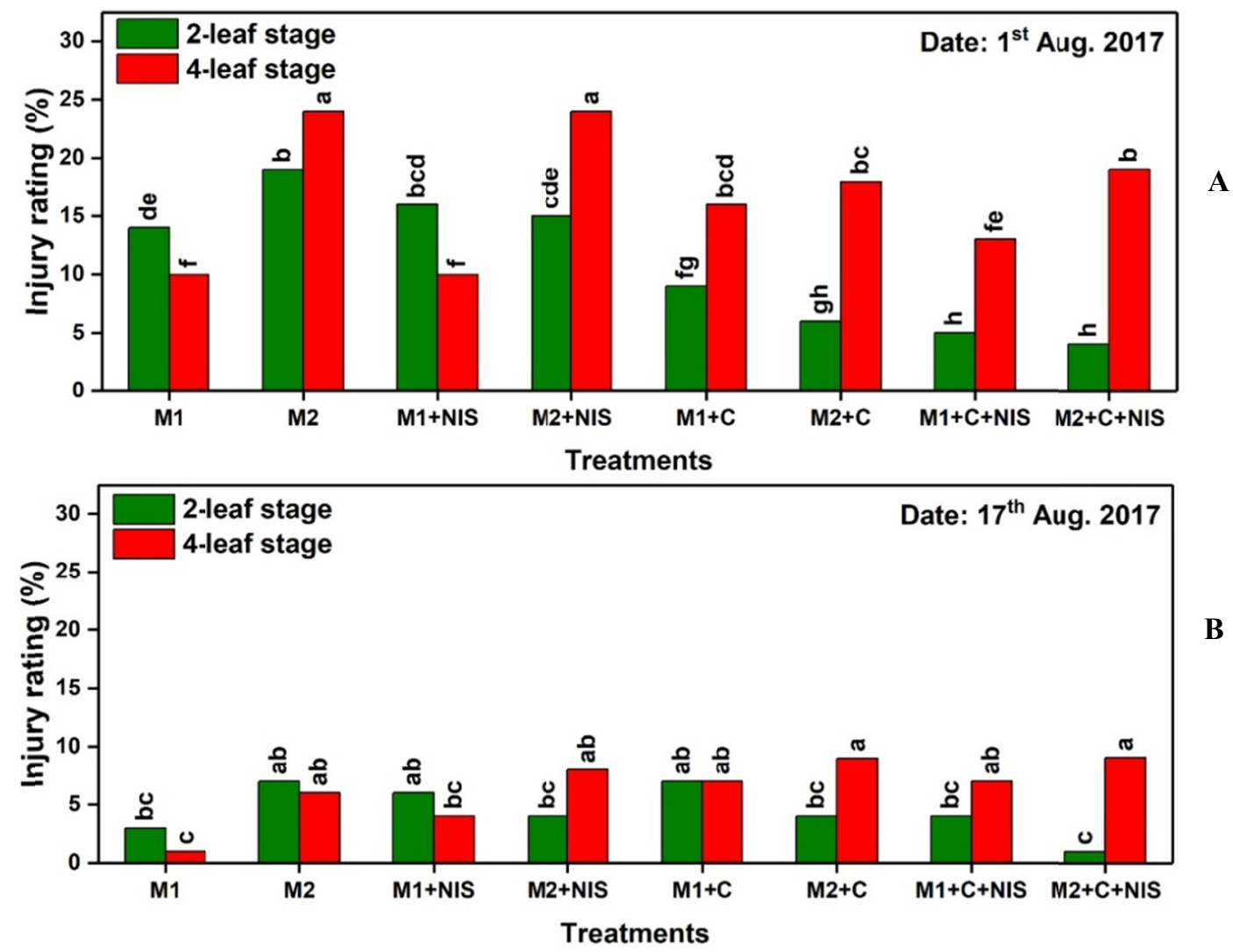

Figure 1. Injury due to herbicide treatments to grain sorghum in 2017 evaluated at 2-leaf and 4-leaf growth stage 4 weeks (A) and 7 weeks (B) after applications. The same letter on bars indicate no significant differences at $\mathrm{p}<$ 0.05. Abbreviations: M1, Mesotrione at $0.07 \mathrm{~kg} \mathrm{ai} \mathrm{ha}^{-1} ; \mathrm{M} 2$, Mesotrione at $1.05 \mathrm{~kg}$ ai ha ${ }^{-1} ; \mathrm{C}$, Dicamba at $0.28 \mathrm{~kg}$ ae ha ${ }^{-1}$; NIS, Non-ionic surfactant at $0.25 \% \mathrm{v} / \mathrm{v}$

Grain sorghum recovered from mesotrione applications over time by 7 WAA for injury ratings assessed on 17 August 2017 (Figure 1B). Seven weeks after herbicide applications, grain sorghum physical injury showed that grain sorghum was more sensitive at 4-leaf growth stage (6\%) than 2-leaf growth stage (4\%) from mesotrione applications (Figure 1B). Application of dicamba with mesotrione $\left(0.105 \mathrm{~kg} \mathrm{ha}^{-1}\right)$ reduced grain sorghum injury when compared to the application of mesotrione alone at $0.105 \mathrm{~kg} \mathrm{ha}^{-1}$ at 2-leaf growth stage. Adding of dicamba to mesotrion reduced grain sorghum injury when application was made at 2-leaf grain sorgum (Figure 1A). Also, addition of dicamba + mesotrion + NIS tank-mix reduced grain sorghum injury when application was made at 2 leaf grain sorghum but not at 4 leaf geain sorghum.

Grain sorghum plant heights were affected by the main effects of herbicide treatments in 2017 (Table 4). Sorghum plant height was $123 \mathrm{~cm}$ in non-treated check, which was significantly higher than plant heights in all other herbicide treatments except in mesotrione $\left(0.105 \mathrm{~kg} \mathrm{ha}^{-1}\right)+$ NIS $(121 \mathrm{~cm})$ (Figure 2). Application of dicamba with mesotrione reduced plant height when compared to the application of mesotrione alone, irrespective of the application rate of mesotrione in 2017. 
Similar to plant heights, percent grain sorghum heading was significantly affected by the main effect of herbicide treatments. Percent grain sorghum heading ranged from 97 to $99 \%$ regardless of herbicide treatments or grain sorghum growth stages, whereas the percent heading in nontreated check was 100\% (Figure 2).
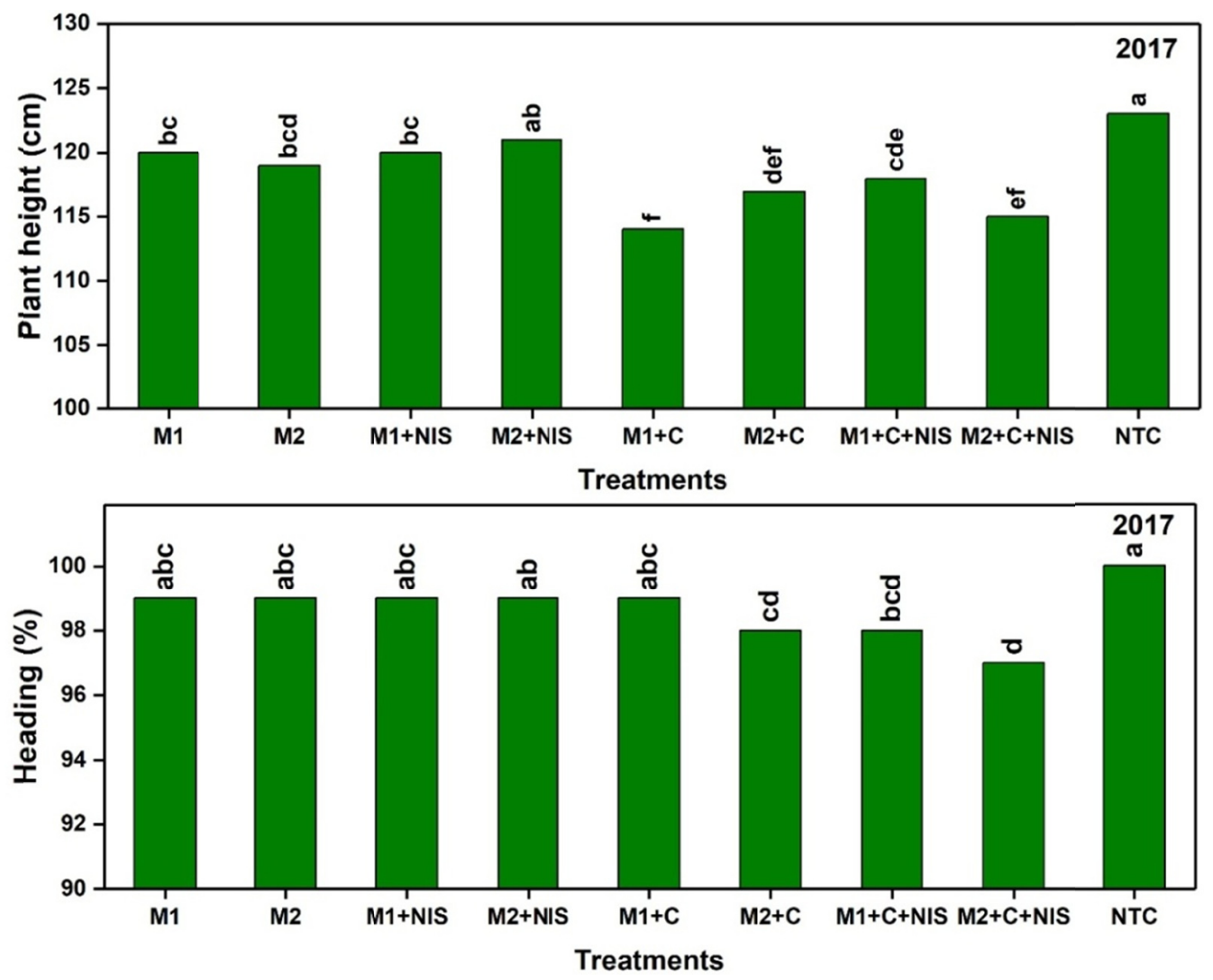

Figure 2. Difference in plant height and grain sorghum heading due to herbicide treatments in 2017. The same letter on bars indicate no significant differences between treatments at $p<0.05$. Abbreviations: M1, Mesotrione at $0.07 \mathrm{~kg}_{\text {ai ha }}{ }^{-1} ; \mathrm{M} 2$, Mesotrione at $1.05 \mathrm{~kg}$ ai ha ${ }^{-1} ; \mathrm{C}$, Dicamba at $0.28 \mathrm{~kg} \mathrm{ae} \mathrm{ha}^{-1}$; NIS, Non-ionic surfactant at $0.25 \% \mathrm{v} / \mathrm{v}$; NTC, Nontreated check

Grain sorghum yield was affected by the main effects of herbicide application timing and interaction of herbicide application timing and herbicide treatments (Table 4 and Figure 3). At 2-leaf application timing for herbicide treatments, the mesotrione at $0.07 \mathrm{~kg} \mathrm{ha}^{-1}+$ dicamba + NIS had $4444 \mathrm{~kg} \mathrm{ha}^{-1}$ greater sorghum yield than Mesotrione at $0.105 \mathrm{~kg} \mathrm{ha}^{-1}+$ NIS. At 4-leaf sorghum application stage, mesotrione applied at $0.07 \mathrm{~kg} \mathrm{ha}^{-1}$ resulted in greater grain yield than all other herbicide treatments, except mesotrione $\left(0.105 \mathrm{~kg} \mathrm{ha}^{-1}\right)+\mathrm{NIS}$. Addition of dicamba to the mesotrion $\left(0.07 \mathrm{~kg} \mathrm{ha}^{-1}\right)$ plus NIS numerically increased grain sorghum yield when application was made at 2-leaf grain sorghum stage probably due safening (reduced injury) effect of dicamba. 


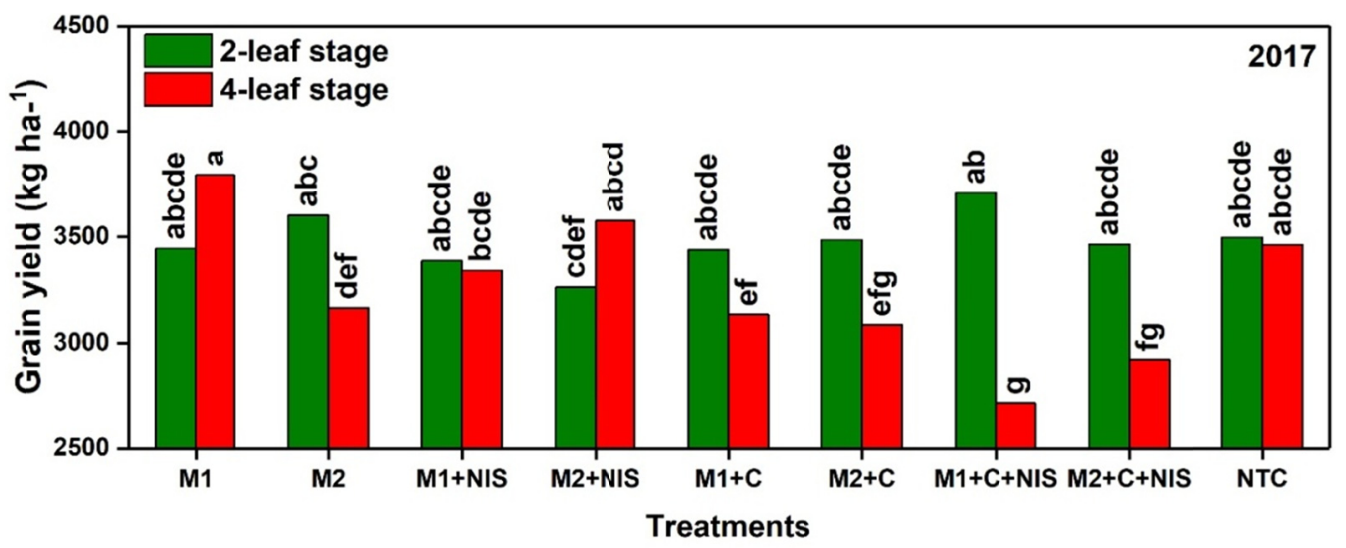

Figure 3. Grain sorghum yield due to herbicide treatments in 2017. The same letter on bars indicate no significant differences between treatments at $\mathrm{p}<0.05$. Abbreviations: M1, Mesotrione at $0.07 \mathrm{~kg}$ ai ha ${ }^{-1} ; \mathrm{M} 2$, Mesotrione at $1.05 \mathrm{~kg}$ ai ha ${ }^{-1}$; C, Dicamba at $0.28 \mathrm{~kg}$ ae ha ${ }^{-1}$; NIS, Non-ionic surfactant at $0.25 \% \mathrm{v} / \mathrm{v}$; NTC, Nontreated check

\subsection{Year 2018}

There were no significant differences in grain sorghum injury based on herbicide treatments or application timing from mesotrione applications on 9 July and 2 August evaluations (data not shown) (Table 5). However, grain sorghum injury was significantly different based on mesotrione applications on $7^{\text {th }}$ August evaluations (Figure 4). Mesotrione application alone at 0.07 and $0.105 \mathrm{~kg} \mathrm{ha}^{-1}$ caused a $6 \%$ injury to sorghum plants. Adding dicamba to the mesotrione tank-mix reduced the level of grain sorghum injury by 1 to $2 \%$, indicating safening effect of dicamba in terms of grain sorghum injury from mesotrione application. However, the addition of NIS with dicamba and mesotrione did not reduce injury to sorghum plants. Plant height and percent heading were not significantly affected by the herbicide treatments or application timing in 2018 (Table 5) (data not shown).

Table 5. Probability values for year 2018 data generated from the statistical model associated with injury ratings, plant height, sorghum heading, and sorghum grain yield determined for herbicide treatments and application timing

\begin{tabular}{|c|c|c|c|c|c|c|}
\hline \multirow{2}{*}{ Source of variation } & \multirow{2}{*}{ df } & \multicolumn{3}{|c|}{ Injury rating (2018) } & \multirow{2}{*}{ Plant height (cm) } & \multirow{2}{*}{ Heading $(\%)$} \\
\hline & & 19 July & 2 August & 7 August & & \\
\hline & & & p-value & & & \\
\hline Herbicide Treatment (HT) & 8 & 0.3250 & 0.4805 & 0.0064 & 0.5192 & 0.8318 \\
\hline Application Timing (AT) & 1 & 0.0724 & 0.3961 & 0.7690 & 0.6943 & 0.3382 \\
\hline $\mathrm{HT} \times \mathrm{AT}$ & 8 & 0.4777 & 0.6904 & 0.2509 & 0.7596 & 0.9957 \\
\hline
\end{tabular}




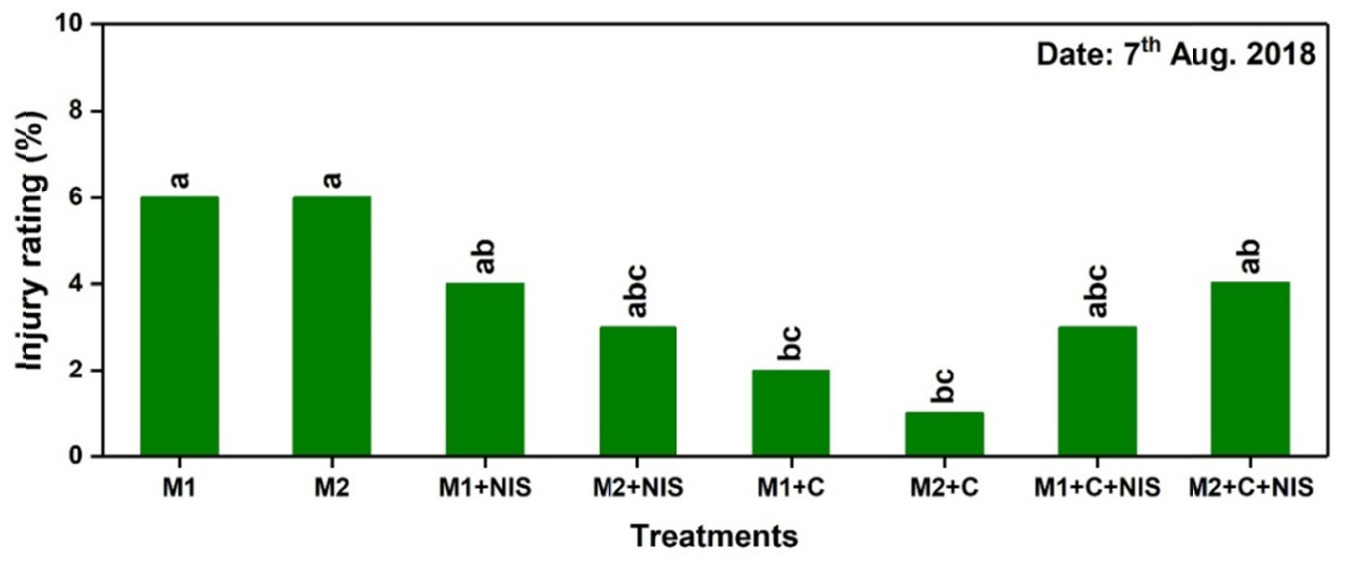

Figure 4. Injury due to herbicide treatments to grain sorghum in 2018. The same letter on bars indicate no significant differences between treatments at $\mathrm{p}<0.05$. Abbreviations: $\mathrm{M} 1$, Mesotrione at $0.07 \mathrm{~kg} \mathrm{ai} \mathrm{ha}^{-1} ; \mathrm{M} 2$, Mesotrione at $1.05 \mathrm{~kg}_{\text {ai ha }}{ }^{-1}$; C, Dicamba at $0.28 \mathrm{~kg}_{\text {ae ha }}{ }^{-1}$; NIS, Non-ionic surfactant at $0.25 \% \mathrm{v} / \mathrm{v}$

Mesotrione inhibits the hydroxyphenylpyruvate dioxygenase (HPPD) enzyme, which disrupts carotenoid biosynthesis and results in inhibition of plastoquinone synthesis (Duke, Dayan, Romagni, \& Rimando, 2000; Wichert, Townson, Bartlett, \& Foxon, 1999). Plastoquinone is a cofactor for phytoene desaturase, a necessary enzyme for carotenoid synthesis and it is also involved in the phosphorylation process. In our study, injury to sorghum plants was observed due to mesotrione applications. Similar to our study, Horky and Martin (2005) reported $20 \%$ chlorosis on sorghum plants due to mesotrione when it was applied post-emergence at $70.5 \mathrm{~g}$ ai $\mathrm{ha}^{-1}$. Miller and Regehr (2002) observed that early POST application of mesotrione caused severe plant injury, such as 40 to $60 \%$ bleaching, but less injury was caused with late POST applications.

Yield reduction due to mesotrione alone application at a lower rate was not present when mesotrione was applied at the 2-leaf stage in our study. Similarly, Abit, Al-Khatib, Stahlman, and Geier (2012) did not find any significant yield reductions inspite of severe mesotrione injury to grain sorghum. The authors reported that yield reduction was not well correlated with the visible mesotrione injury. Adding dicamba to the tank mix with mesotrione resulted in lowering physical injury to sorghum plants in our study indicating the safening effect of dicamba to mesotrione applications in sorghum. Similarly, Brown et al. (2004) also reported that dicamba safened grain sorghum from metsulfuron injury. However, adding dicamba also reduced yield of grain sorghum when mesotrione was applied at a lower rate of $0.07 \mathrm{~kg} \mathrm{ha}^{-1}$ at later timing (4-leaf growth stage). The use of dicamba with mesotrione also reduced plant height in 2017. This indicates that dicamba should be avoided to be used with mesotrione at later application timing (4-leaf stage of grain sorghum).

\section{Conclusions}

The presence of weeds can result in severe yield losses in grain sorghum. There are limited herbicide options for weed management in grain sorghum. Mesotrione is labeled for preemergence application in grain sorghum since its post-emergence application can cause leaf injury in grain sorghum. Our study evaluated the use of dicamba with mesotrione in a tank mix to safen grain sorghum from injury. Our study results indicate that adding dicamba to mesotrione (postemergence) safens grain sorghum from injury caused by mesotrione alone. Therefore, mesotrione could be an option to use for as postemergence application for weed management in grain sorghum.

\section{Acknowledgements}

This publication is a contribution of the Mississippi Agricultural and Forestry Experiment Station. This material is based upon work that is supported by the National Institute of Food and Agriculture, U.S. Department of Agriculture, Hatch project under accession number 230080.

\section{References}

Abit, M. J. M., Al-Khatib, K., Regehr, D. L., Tuinstra, M. R., Claassen, M. M., Geier, P. W., ... Currie, R. S. (2009). Differential response of grain sorghum hybrids to foliar-applied mesotrione. Weed Technology, 23(1), 28-33. https://doi.org/10.1614/WT-08-086.1 
Abit, M. J. M., Al-Khatib, K., Stahlman, P. W., \& Geier, P. W. (2012). Response of aryloxyphenoxypro pionate-resistant grain sorghum to quizalofop at various rates and application timings. Weed Technology, 26(1), 14-18. https://doi.org/10.1614/WT-D-11-00020.1

Bararpour, M. T., Norsworthy, J. K., Hale, R. R., \& Jones, G. T. (2017). Safening grain sorghum to postemergence application of mesotrione. Paper presented at the Proceedings of the Southern Weed Science Society 70th Annual Meeting, Hyatt Regency-The Wynfrey Hotel Birmingham, AL.

Brown, D. W., Al-Khatib, K., Regehr, D. L., Stahlman, P. W., \& Loughin, T. M. (2004). Safening grain sorghum injury from metsulfuron with growth regulator herbicides. Weed science, 52(3), 319-325. https://doi.org/ 10.1614/P2002-074

Duke, S., Dayan, F., Romagni, J., \& Rimando, A. (2000). Natural products as sources of herbicides: current status and future trends. Weed Research (Oxford), 40(1), 99-111. https://doi.org/10.1046/j.1365-3180. 2000.00161.x

Horky, K. T., \& Martin, A. R. (2004). Evaulation of preemergence weed control programs in grain sorghum. NCWSS Research Report. Lincoln, NE.

Horky, K. T., \& Martin, A. R. (2005). Evaluation of preemergence weed control programs in grain sorghum (pp. 30-32). Weed Control in Specialty Crops, Lincoln, NE.

Janak, T. W., \& Grichar, W. J. (2016). Weed control in corn (Zea mays L.) as influenced by preemergence herbicides. International Journal of Agronomy, 2016(4), 1-9. https://doi.org/10.1155/2016/2607671

Knezevic, S. Z., Horak, M. J., \& Vanderlip, R. L. (1997). Relative time of redroot pigweed (Amaranthus retroflexus L.) emergence is critical in pigweed-sorghum [Sorghum bicolor (L.) Moench] competition. Weed science, 45(4), 502-508. https://doi.org/10.1017/S0043174500088731

Miller, J., \& Regehr, D. (2002). Grain sorghum tolerance to postemergence mesotrione applications. Paper presented at the Proc. N. Cent. Weed Sci.

Mitchell, G., Bartlett, D. W., Fraser, T. E. M., Hawkes, T. R., Holt, D. C., Townson, J. K., \& Wichert, R. A. (2001). Mesotrione: A new selective herbicide for use in maize. Pest Management Science: Formerly Pesticide Science, 57(2), 120-128. https://doi.org/10.1002/1526-4998(200102)57:2\%3C120::AID-PS254\% 3E3.0.CO;2-E

Moore, J. W., Murray, D. S., \& Westerman, R. B. (2004). Palmer amaranth (Amaranthus palmeri) effects on the harvest and yield of grain sorghum (Sorghum bicolor). Weed Technology, 18(1), 23-29. https://doi.org/ 10.1614/WT-02-086

Shipley, J., \& Wiese, A. (1969). Economics of weed control in sorghum and wheat (Progress Report MP-909, pp. 3-8). Amarillo, TX: Texas Agricultural Experimental Station.

Smith, K., \& Scott, B. (2010). Weed control in grain sorghum. In L. Espinoza \& J. Kelley (Eds.), Grain Sorghum Production Handbook (pp. 47-49). Little Rock, AR, USA: Cooperative Extension Service, University of Arkansas.

Sutton, P., Richards, C., Buren, L., \& Glasgow, L. (2002). Activity of mesotrione on resistant weeds in maize. Pest management science, 58(9), 981-984. https://doi.org/10.1002/ps.554

Wichert, R., Townson, J., Bartlett, D., \& Foxon, G. (1999). Technical review of mesotrione, a new maize herbicide. Paper presented at the Brighton Crop Protection Conference Weeds.

\section{Copyrights}

Copyright for this article is retained by the author(s), with first publication rights granted to the journal.

This is an open-access article distributed under the terms and conditions of the Creative Commons Attribution license (http://creativecommons.org/licenses/by/4.0/). 